\title{
How I do a brain death examination: the tools of the trade
}

\author{
Eelco F. M. Wijdicks ${ }^{*}$ (D)
}

Brain death has been accepted universally, although practice differences have eluded consensus [1, 2]. Laws and guidelines have not appreciably changed $[3,4]$ nor have tools of the trade. The following principles remain: establish the reason for coma (most important), exclude known/unknown confounders (equally important), ascertain the futility of intervention (decided before), prepare the patient for testing (to optimize resolution), and acknowledge clinical examination as the benchmark (essential) [5]. One should ask three questions: Have I tried everything to change the clinical picture? Can I proceed? Can I be fooled?

Brain death examination is hands-on (Fig. 1) and focused on brainstem function: from mesencephalon down to the dorsal medulla oblongata. These seemingly few tests are more than sufficient; other tests (e.g., IV atropine, nasal tickle, and ciliospinal reflex) add nothing. In the mesencephalon, test only one reflex circuit, the pupil response to a high-intensity flashlight. Pupils in brain death are not "fixed and dilated" but mid-position $(4-6 \mathrm{~mm})$ due to loss of sympathetic and parasympathetic input. I use a magnifying glass while others use a pupilometer; the only difference between them is several thousand dollars. Several reflex circuits are tested in the pons: absent corneal reflexes; squirt water on the cornea or strike with cotton from the conjunctiva toward and on the cornea. (Sadly, one in five surveyed members of professional organizations does not test correctly [6]). To elicit the oculocephalic reflex, hold the head firmly with two hands while keeping the

\footnotetext{
*Correspondence: wijde@mayo.edu

Neurosciences Intensive Care Unit, Saint Marys Hospital, Mayo Clinic, 200 First Street SW, Rochester, MN 55905, USA
}

eyelids open with thumbs. Eye movement (opposite to head movement) is induced by fast head turning from a middle portion to $90^{\circ}$ on both sides. (Obviously, omit this test in a trauma patient with a cervical collar.) Also, eye movements should be absent after irrigating the tympanum with $30 \mathrm{cc}$ ice water. (The normal response in a comatose patient is a very slow deviation of the eyes toward the syringe.) I place pen marks on the eyelid to reference the level of the pupil. Pain grimaces should be absent upon deep pressure to nail beds (reflex hammer), pressure on the supraorbital nerve (thumb), or deep pressure on the temporomandibular joint condyles (index fingers).

In the medulla oblongata, test the gag response with a tongue depressor or suction device into the oral cavity. As it is difficult to see, I insert a gloved finger past the uvula, a more reliable stimulus. Catheter passages through the endotracheal tube while providing suctioning pressure should not elicit a cough response.

Noxious stimuli should not produce a motor response. While there might be a spinally mediated response (i.e., brief, slow movements in the upper limbs, flexion in the fingers, or arm lifting), they are never coordinated decerebrate or decorticate responses [3-6] and diminish with repeated stimulation. Plantar reflexes are absent, but upward toe flexion may occur with a triple-flexion response.

Next is the apnea test. Keep it simple [7]. Review the chest $\mathrm{X}$-ray and blood gas and pre-oxygenate to $\mathrm{PaO}_{2}>200 \mathrm{mmHg}$. The factors predicting a problematic apnea test are (1) insufficient pre-oxygenation, (2) high A-a gradient (>300), (3) oxygen through a T-piece, (4) systolic hypotension $(<90 \mathrm{mmHg})$, and (5) baseline acidosis (arterial $\mathrm{pH}<7.30$ ). Pulmonary edema (or 


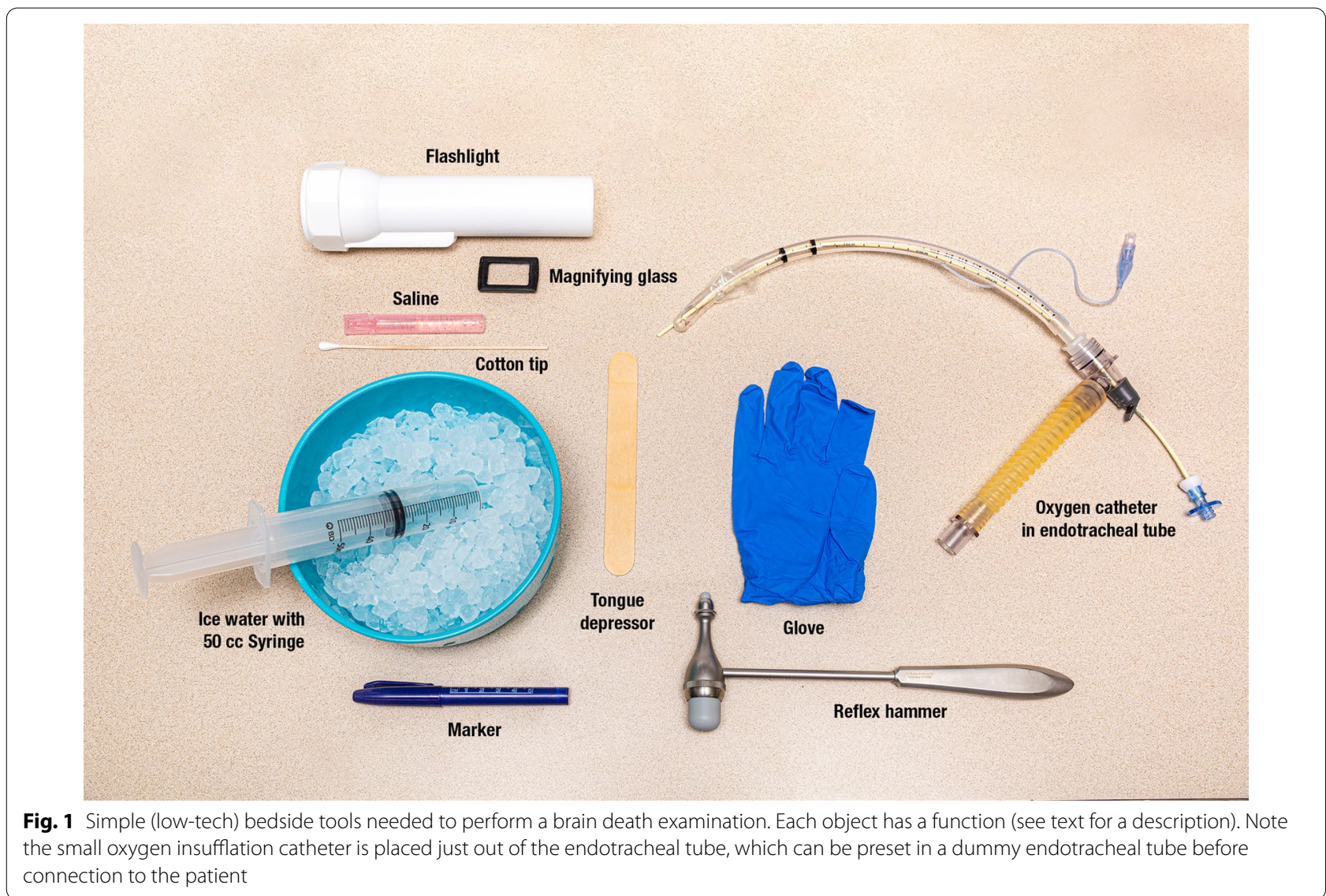

massive infiltrates) produces a significant A-a gradient and failure to oxygenate during the test. In some patients, neurogenic pulmonary edema resolves in $48 \mathrm{~h}$, still allowing an apnea test. Especially germane today, apnea testing is unsafe in COVID-19 pneumonia with neurologic complications due to diffuse exudative epithelial denudation of alveoli. A pretest high PEEP may complicate oxygenation after disconnecting the patient; pretest recruitment maneuver and a $20-\mathrm{cm} \mathrm{H}_{2} \mathrm{O}$ CPAP valve may be used.

Disconnect the ventilator and flow oxygen $(6 \mathrm{~L} /$ min) through a catheter advanced to the carina (Fig. 1). Monitor oxygen saturation, pulse, and blood pressure while looking for breathing. Breathing occurs quickly (maybe only an early single gasp). When breathing is absent, declare brain death at a $\mathrm{pCO}_{2}$ target of $60 \mathrm{mmHg}$ or with a $20 \mathrm{mmHg}$ increase. Conventionally, time of death is the time of the second blood gas result. Complications, usually minor with good preparation, become major with bad or non-standard preparation [7-10]. Our decades-long experience with this oxygen diffusion technique has been safe and aborted in only $3 \%$ of 212 tests [9].
ECMO requires adjustment. Blending $\mathrm{CO}_{2}$ into the oxygenator is the best option. We estimate that an $8 \%$ volume of $\mathrm{CO}_{2}$ results in $\mathrm{paCO}_{2}$ of $65-70 \mathrm{mmHg}$. If blending is not available, $\mathrm{CO}_{2}$ can only be increased by markedly diminishing sweep gas, but this technique risks hypoxia. Additionally, reducing the sweep gas increases the number of expensive blood gasses; it is anyone's guess where $\mathrm{PaCO}_{2}$ will end up $[8,10]$.

Ultimately, the physician determining brain death must use his own best judgment. Sequential steps are essential (Fig. 2). Whether one absent pontomesencephalic reflex should prompt an ancillary test is debatable, because death comes with loss of medulla oblongata function. Focus on the functionality of the lower brainstem because there is a vertical loss. It is a one-way door. Ancillary ("confirmatory") tests remain mandated in a minority of countries as a safeguard or when unable to complete the apnea test. But studies of ancillary tests lacked appropriate controls; comparisons between tests show major discrepancies and technical problems (or even timely availability). In several countries, repeated comprehensive evaluations are required. No literature-based evidence supports a second 


\section{ASSESSMENTS TO DECLARE A PATIENT BRAIN DEAD}

\author{
PREREQUISITES (ALL MUST BE CHECKED) \\ 1. $\square$ Coma, irreversible and cause known \\ 2. $\square$ Neuroimaging explains coma \\ 3. $\square$ Sedative drug effect absent \\ (if indicated, order a toxicology screen) \\ 4. $\square \quad$ No residual effect or paralytic drug \\ (if indicated, use peripheral nerve stimulator) \\ 5. $\square$ Absence of severe acid-base, electrolyte, \\ or endocrine abnormality \\ 6. $\square$ Normal or near normal temperature \\ (core temperature $\geq 36^{\circ} \mathrm{C}$ ) \\ 7. $\square$ Systolic blood pressure $\geq 100 \mathrm{mmHg}$ \\ 8. $\square \quad$ No spontaneous respirations
}

EXAMINATION (ALL MUST BE CHECKED)
9. $\square \quad \begin{aligned} & \text { Pupils non-reactive to bright light } \\ & \text { (typically mid-position at 5-7 mm) }\end{aligned}$
10. $\square \quad \begin{aligned} & \text { Corneal reflexes absent } \\ & \text { (use both saline jet and tissue touch) }\end{aligned}$
11. $\square \quad \begin{aligned} & \text { Eyes immobile, oculocephalic reflexes absent } \\ & \text { (tested only if C-spine integrity ensured) }\end{aligned}$
12. $\square \quad \begin{aligned} & \text { Oculovestibular reflexes absent } \\ & \text { (50 cc of ice water in each ear sequentially) }\end{aligned}$
13. $\square \quad \begin{aligned} & \text { No facial movement to noxious stimuli at } \\ & \text { supraorbital nerve or temporomandibular joint } \\ & \text { compression } \\ & \text { (absent snout and rooting reflexes in neonates) }\end{aligned}$
14. $\square \quad \begin{aligned} & \text { Gag reflex absent } \\ & \text { (gloved index finger to posterior pharynx) }\end{aligned}$
15. $\square \quad \begin{aligned} & \text { Cough reflex absent to tracheal suctioning } \\ & \text { (at least } 2 \text { passes) }\end{aligned}$
16. $\square \quad \begin{aligned} & \text { No motor response to noxious stimuli in all } 4 \text { limbs } \\ & \text { (triple flexion response is most common } \\ & \text { spinal-mediated reflex) }\end{aligned}$

Fig. 2 Steps in declaring brain death

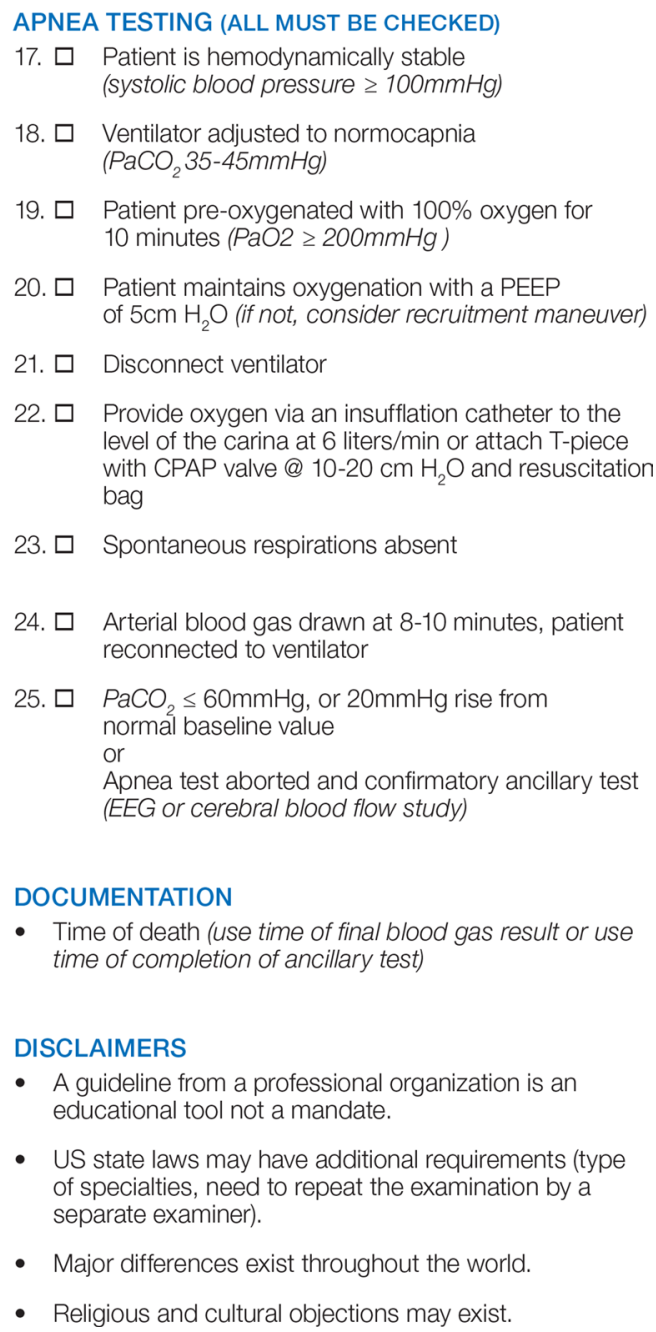

19. $\square$ Patient pre-oxygenated with $100 \%$ oxygen for 10 minutes ( $\mathrm{PaO} 2 \geq 200 \mathrm{mmHg}$ )

20. $\square$ Patient maintains oxygenation with a PEEP of $5 \mathrm{~cm} \mathrm{H}_{2} \mathrm{O}$ (if not, consider recruitment maneuver)

21. $\square$ Disconnect ventilator

22. $\square$ Provide oxygen via an insufflation catheter to the level of the carina at 6 liters $/ \mathrm{min}$ or attach T-piece with CPAP valve @ 10-20 cm H $\mathrm{H}_{2} \mathrm{O}$ and resuscitation bag

23. $\square$ Spontaneous respirations absent

24. $\square$ Arterial blood gas drawn at 8-10 minutes, patient reconnected to ventilator

25. $\square \mathrm{PaCO}_{2} \leq 60 \mathrm{mmHg}$, or $20 \mathrm{mmHg}$ rise from normal baseline value or Apnea test aborted and confirmatory ancillary test (EEG or cerebral blood flow study)

DOCUMENTATION

- Time of death (use time of final blood gas result or use time of completion of ancillary test)

\section{DISCLAIMERS}

- A guideline from a professional organization is an educational tool not a mandate.

- US state laws may have additional requirements (type of specialties, need to repeat the examination by a separate examiner).

- Major differences exist throughout the world.

- Religious and cultural objections may exist.

examination contradicting the first. Longer wait times are unsupported by evidence or facts.

Training is warranted but current mannequin-based programs lack validity. Without built-in brainstem reflexes, mannequins cannot simulate spared brainstem reflexes with the notable exception of preserved breathing drive. Simulation is best used to teach the recognition of confounders [11].

Every intensive care physician is able to perform a full clinical brain death examination. Do not resolve clinical uncertainties with an ancillary test with poor specificity. Proceed when you can-with colleagues if they are available. If available, ask to involve a neurointensivist. For now, we must trust the examiner is fully knowledgeable and competent in all aspects.

\section{Acknowledgements}

The author thanks Lea Dacy, Mayo Department of Neurology for superb editing.

\section{Authors' contributions}

The author is solely responsible for conception, acquisition, and interpretation of the material and is the sole author of the submitted version. The author read and approved the final manuscript.

\section{Funding}

None. 


\section{Availability of data and materials}

All data generated or analyzed during this study are included in this published article.

\section{Ethics approval and consent to participate}

Not applicable.

\section{Consent for publication}

Not applicable.

\section{Competing interests}

The author declares he has no competing interests.

Received: 15 October 2020 Accepted: 4 November 2020

Published online: 18 November 2020

\section{References}

1. Bernat JL. Comment: Is international consensus on brain death achievable? Neurology. 2015;84:1878.

2. Greer DM, Shemie SD, Lewis A, Torrance S, Varelas P, Goldenberg FD, Bernat $\mathrm{J}$, Souter M, Topcuoglu MA, Alexandrov AW, et al. Determination of brain death/death by neurologic criteria: the world brain death project. JAMA. 2020. https://doi.org/10.1001/jama.2020.11586.

3. Lewis A, Bakkar A, Kreiger-Benson E, Kumpfbeck A, Liebman J, Shemie SD, Sung G, Torrance S, Greer D. Determination of death by neurologic criteria around the world. Neurology. 2020;95:e299-309.

4. Wahlster S, Wijdicks EF, Patel PV, Greer DM, Hemphill JC 3rd, Carone M, Mateen FJ. Brain death declaration: practices and perceptions worldwide. Neurology. 2015:84:1870-9.
5. Wijdicks EF, Varelas PN, Gronseth GS, Greer DM. American Academy of $\mathrm{N}$. Evidence-based guideline update: determining brain death in adults: report of the Quality Standards Subcommittee of the American Academy of Neurology. Neurology. 2010;74:1911-8.

6. Maciel CB, Youn TS, Barden MM, Dhakar MB, Zhou SE, Pontes-Neto OM, Silva GS, Theriot JJ, Greer DM. Corneal reflex testing in the evaluation of a comatose patient: an ode to precise semiology and examination skills. Neurocrit Care. 2020;33:399-404.

7. Busl KM, Lewis A, Varelas PN. Apnea testing for the determination of brain death: a systematic scoping review. Neurocrit Care. 2020. https://doi. org/10.1007/s12028-020-01015-0.

8. Beam WB, Scott PD, Wijdicks EFM. The physiology of the apnea test for brain death determination in ECMO: arguments for blending carbon dioxide. Neurocrit Care. 2019:31:567-72.

9. Daneshmand A, Rabinstein AA, Wijdicks EFM. The apnea test in brain death determination using oxygen diffusion method remains safe. Neurology. 2019;92:386-7.

10. Migdady I, Stephens RS, Price C, Geocadin RG, Whitman G, Cho SM. The use of apnea test and brain death determination in patients on extracorporeal membrane oxygenation: a systematic review. J Thorac Cardiovasc Surg. 2020. https://doi.org/10.1016/j.jtcvs.2020.03.038.

11. Hocker S, Schumacher D, Mandrekar J, Wijdicks EF. Testing confounders in brain death determination: a new simulation model. Neurocrit Care. 2015:23:401-8.

\section{Publisher's Note}

Springer Nature remains neutral with regard to jurisdictional claims in published maps and institutional affiliations.
Ready to submit your research? Choose BMC and benefit from:

- fast, convenient online submission

- thorough peer review by experienced researchers in your field

- rapid publication on acceptance

- support for research data, including large and complex data types

- gold Open Access which fosters wider collaboration and increased citations

- maximum visibility for your research: over $100 \mathrm{M}$ website views per year

At $\mathrm{BMC}$, research is always in progress.

Learn more biomedcentral.com/submissions 